\title{
Lokacije usmenoknjiževnog pripovijedanja - pripovijedanje oko vatre, $u$ gostionici i na bdjenju uz pokojnika
}

Denis Vekić*

dvekic@unizd.hr https://doi.org/10.31192/np.16.3.1

UDK: $398.5(1-7)$

Izvorni znanstveni rad / Original scientific paper

Primljeno: 22. kolovoza 2018.

Prihvaćeno: 28. listopada 2018.

Rad se bavi lokacijama na kojim se stvaraju i prenose usmenoknjiževni oblici usmjeravajući proučavanje na komunikacijski aspekt koji potiču mjesta koja su pogodna za izražavanje govorničkog i usmenoknjiževnog umijeća. Pozornost je posvećena kontekstu usmenoknjiževnog izražavanja okupljenih oko vatre za koju neki stručnjaci u novije vrijeme smatraju da je jedan od osnovnih faktora informacijskog razvoja drevnih društava. Rad se osvrće na gostionicu/krčmu/ kafić kao mjesta pogodna za plodno usmenoknjiževno izražavanje upravo zbog sociološke $i$ antropološke vrijednosti te lokacije u razmjeni informacija nekog društva. Na kraju, rad se bavi specifičnošću u usmenoknjiževnoj transmisijskoj funkciji - pričanju priča i drugih usmenoknjiževnih oblika dok ukućani i obitelj bdiju nad pokojnikom. Suprotno pričanjima oko vatre i u gostionici, ovaj se narativni specifikum manifestira usprkos delikatnosti situacije i nimalo pogodnoj atmosferi za emisiju usmenoknjiževnih oblika.

Ključne riječi: vatra, gostionica, usmena književnost, pripovijedanje.

\section{Uvod}

Mjesta na kojem se odvijaju pripovijedanja priča, a napose predaja, mogu biti raznolika i ovisna o prigodi i prostoru. Izvođenje usmene književnosti se promatra u kontekstu odnosa izvođača i recipijenta i u performativu kao kategoriji usmenoknjiževne ostvarivosti. Izvođenje usmene književnosti uvijek je

\footnotetext{
* Dr. sc. Denis Vekić, Odjel za kroatistiku i slavistiku, Sveučilište u Zadru, Obala kralja Petra Krešimira IV., br. 2, HR-23000 Zadar.
} 
usko vezano uz spontanost i prepoznavanje kvalitetnog sadržaja i izvođača/ kazivača koji od prijenosa informacije stvara situaciju, događaj koji je gotovo jednake vrijednosti kao i sadržaj koji se iznosi. Izvođenje, kazivanje usmene književnosti postaje u suvremenijim antropološkim istraživanjima predmet proučavanja upravo zbog važnosti neverbalne komunikacije u kazivanju, zbog bliskog kontakta između kazivača i zajednice te kazivačke situacije koja postaje performativ pojedinca koji doprinosi kulturalnom produbljenju zajednice. Proučavajući dva tipa inducirane kazivačke situacije (»performans kao spektakl« i »performans kao postignuće«) Luciana Hartmann u svom istraživanju ističe važnost konteksta pored kazivanog narativa, korištenja poetičkog jezika i razumijevanja odnosa pojedinca i zajednice, a posebno važnost razumijevanja iskustva sudjelovanja. ${ }^{1}$ Nadopunjujući stariji koncept promatranja usmene književnosti u domeni komunikacije, Bauman ističe odgovornost izvođača prema recipijentima koji očekuju prezentiranje komunikacijskih kompetencija i izvođenja kao jednog od načina korištenja govora, načina govorenja i komunikacije. ${ }^{2}$ Također ističe izvođače/kazivače kao one talentirane pojedince koji su $\mathrm{u}$ svom usmenom performativu ponekad recipijentima zanimljiviji i važniji od sadržaja koji iznose. ${ }^{3}$

Pozornost ovog rada usmjerena je na kazivačke lokacije koje svojom socijalnom funkcijom mogu poslužiti kao specifičan prostor koji pogoduje usmenoknjiževnom performativu. U velikoj količini prikupljenih usmenoknjiževnih tekstova uočava se u bilješkama i u razgovoru s kazivačima da postoje lokacije koje su uobičajene za pripovijedanje ili su na neki način pogodnije od drugih kazivačkih lokacija. U tom procesu umjetničkog usmenoknjiževnog izričaja i komunikacijske razmjene informacija između kazivača i recipijenta samo izvođenje, atmosfera i lokacija izvođenja može biti ključ u prihvaćanju pojedinog narativa i njegova boljeg prijenosa $\mathrm{u}$ zajednici.

Pripovijedanje uz vatru ognjišta je praksa koju je danas teško pronaći u izvornom obliku, no osobnim svjedočenjem takvog oblika pripovijedanja mogu se iznijeti opažanja i zaključci vezani za doživljajnost intimnog prostora domaćinstva kao pokretača plodnog usmenoknjiževnog izričaja. Sličan slučaj je i s bdjenjem uz pokojnika. Budući da se takva praksa više ne obavlja, u radu je riječ o osobnim iskustvima autora koji su potkrijepljeni iskustvima i drugih poznatijih istraživača. U kontekstu aktualnosti, gostionica kao mjesto pripovijedanja jedina nudi mogućnost suvremenijeg istraživanja i proučavanja, no koherentnost zajednice koja obitava u njima ne daje mnogo mogućnosti u proučavanju intimnijih kazivačkih situacija, osim onih koje se mogu proučavati

\footnotetext{
${ }^{1}$ Usp. Luciana HARTMANN, Performance e experiência nas narrativas orais da fronteira entre Argentina, Brasil e Uruguai, Horizontes antropológicos, 11 (2005) 24, 125-153.

${ }^{2}$ Usp. Richard BAUMAN, Verbal Art as Performance, American antropologist, 77 (1975) 290311, 293.

${ }^{3}$ Richard BAUMAN, Verbal Art as Performance, Long Grove, Illinois, Waveland Press inc., 1977, 5.
} 
promatranjem i opažanjem. Međutim, istraživački zapisi o pripovijedanju uz vatru u interijeru i eksterijeru svjedoče o važnosti prijenosa usmenoknjiževnih oblika u blizini vatre. Kada kazivači uspoređuju mjesta kazivanja onda uvijek istaknu da su najbolja bila ona uz vatru ognjišta te su time hijerarhijski postavili ognjište ispred drugih lokacija pripovijedanja. Stoga se u radu pozornost posvećuje upravo pripovijedanju uz vatru ognjišta s usporednim osvrtom na pripovijedanje uz vatru na otvorenom.

Osim spomenutog kazivanja oko vatre, zastupljena je praksa kazivanja dok se sjedilo na rivi, šetalo, pješice putovalo preko brda, sastajalo ispred crkve i čekalo polnoćku, sjedilo u krčmi, ležalo prije spavanja, odmaralo od rada na polju itd.

Vatra na ognjištu i otvorena vatra u eksterijeru su u pripovjednoj praksi kazivača čest topos kazivanja priča. Osim toga, u starinskoj arhitekturi kućanstva, gostionice i prenoćišta, ognjište zauzima poseban prostor koji se koristi za mnoge kućanske i domaćinske poslove, ali isto tako i za primanje gostiju. Ognjište je jezgra domaćinstva iz prošlih vremena. Ivan Lovrić je još u 18. stoljeću opisao prigodu u kojoj se pripovijedaju priče oko vatre te taj zapis izravno govori o praktičnoj funkciji okupljanja oko vatre. ${ }^{4} \mathrm{U}$ slobodnom razgovoru na vlastitim terenskim istraživanjima kazivači su govorili da je pripovijedanje oko vatre općenito bilo najplodnije jer vatra budi maštu i grije pa svojom toplinom opušta i omogućava lakše uživljavanje u sadržaj ispripovjeđenog. Atmosfera koju pruža pričanje oko vatre je specifična i jako pogodna za razvijanje mašte i za veći utjecaj subliminalnog i podsvjesnog na slušače, ali i na kazivača. Sama »igra" svjetla i sjene, izolacijski aspekt u kojem veliku ulogu igra prizor siluete sugovornika, te tama koja okružuje, stvaraju pogodnu kulisu za pripovijedanje i za pojačan intenzitet recepcije. Prilikom recepcije predaja s fantastičnim elementima podsvjesno interferira s pojedincem te se vrlo lako uspostavlja intiman transmisijski odnos između predaje i recipijenta.

Praksa pripovijedanja odvija se na različitim mjestima pa neka mogu biti vezana i za neku djelatnost: »O prilikama kada se pripovijeda čula sam u Opuzenu ovo: Kad se peče rakija, onda se priča ili kad komišaju kokuruz.. ${ }^{5}$ Bez obzira na mjesto pripovijedanja, pri samoj aktivnosti pripovijedanja, sposobnost kazivača je često testirana upravo izvanjskim utjecajima koji mogu razbiti čvrstu vezu između njega i recipijenata. Vanjski utjecaji i ometala koji dolaze iz neposredne okoline odvlače pozornost recipijenata, ali isto tako mogu zbuniti pripovjedača te ga dovesti u neugodnost kada naruši integritet pripovijedanja i pokvari umjetnički i slušateljski dojam povjednog sadržaja. Stoga:

\footnotetext{
${ }^{4}$ Usp. Ivan LOVRIĆ, Bilješke o putu po Dalmaciji opata Alberta Fortisa i Život Stanislava Sočivice, Zagreb, Izdavački zavod Jugoslavenske akademije, 1948.

${ }^{5}$ Maja BOŠKOVIĆ-STULLI, Folklorna građa s Pelješca i Neretve, IEF rkp. 257, 1956, 6.
} 
»Pripovjedači katkada ponavljaju cijele pasuse, rečenice i riječi upravo zbog slučajnih vanjskih uzrokovanih prekida pričanja nepovezanih s pričom i bez ikakve funkcije u istoj... « ${ }^{6}$

Zbog toga pripovjedač ima delikatan zadatak otklanjanja vanjskog svijeta u pripovijedanju i koncentriranja pažnje svojih slušalaca i gledalaca na sebe. ${ }^{7}$

Intimnost kazivačke situacije zajamčena je u pripovijedanju oko vatre na ognjištu budući da zatvorenost prostora omogućuje odijeljenost od vanjskog prostora te se sudionici okupljaju najčešće u isto vrijeme. Specifičnost pripovijedanja $u$ interijeru proizlazi iz intimnosti zajednice koja se okuplja u domaćinstvu. Koherentnost te zajednice je uvjetovana obiteljskim sponama te omogućuje pripovjedaču da se obraća recipijentima bez umjetničkih ili privatnih barijera. Pričanje oko ognjišta omogućuje zajednici dublji umjetnički izričaj $\mathrm{i}$ involviranost $\mathrm{u}$ pripovijedanju. $\mathrm{U}$ tom intimnom interijeru performativi su izražajniji i korpus usmenoknjiževnih oblika prilagođava se prema željama i potrebama recipijenata koji potiču kazivača na izvođenje specifičnog žanra usmene književnosti.

Drugačije zakonitosti vrijede u pripovijedanju oko vatre u eksterijeru. Izražajnost i spektar usmenoknjiževnih oblika se mijenja prema situaciji, a posebno prema prostoru u kojem se okupljeni sudionici nalaze. Privatni aspekt se izbjegava zbog širine spektra sudionika te se otvorenost prostora doživljava kao mjesto javnog okupljanja. Zbog takvog doživljaja prostora zakonitosti koje su vrijedile u intimi zatvorenog domaćinstva oko ognjišta poprimaju oblik javnog susreta.

\section{Oko vatre}

Mjesta na kojem se odvijaju neinducirana pripovijedanja priča mogu biti raznolika i ovisna o prigodi. Lokacije prikupljačke aktivnosti su ona mjesta na kojima se odvija inducirana kazivačka situacija. Prilikom istraživačkog rada ${ }^{8}$ inducirane kazivačke situacije odvijale su se često u dnevnom boravku domaćinstva u kojem kazivač ili kazivačica živi. Ovisno o temperamentu i karakteru kazivača sjedi se za stolom, kao u slučaju s Nikolom Nikolićem, ili se sjedi na sofi u opuštenoj atmosferi, kao što je slučaj s Ivkom Jerković. Kazivači su naglašavali da su se predaje prepričavale uglavnom uz vatru na ognjištu. Također su nudi-

\footnotetext{
${ }^{6}$ Maja BOŠKOVIĆ-STULLI, Žito posred mora. Usmene priče iz Dalmacije, Split, Književni krug Split, 1993, 24-25.

${ }^{7}$ Usp. Tvrtko ČUBELIĆ, Povijest $i$ historija usmene narodne književnosti. Historijske i literarnoteorijske osnove te genealoški aspekti. Analitičko-sintetički pogledi, Zagreb, Ante i Danica Pelivan, 1990, 133.

${ }^{8}$ Istraživački rad proveden je 2007. i 2013. godine u dolini Neretve. Istraživanje je proveo Denis Vekić i velik dio zabilježenog materijala objavio je i znanstveno obradio 2016. godine u doktorskoj disertaciji Poetika mitskih i demonoloških predaja donjoneretvanskog kraja.
} 
li objašnjenje u kojem se očituje razumijevanje scenske važnosti ognjišta kao mjesta gdje je pogodnije pripovijedati. Kazivači su u razgovoru na terenskom istraživanju objašnjavali da »kod vatre«, iz njima nepoznatih razloga, sve priče »bolje zvuče«. Osim toga, vjerodostojnost predaje o vješticama bi bila potvrđena pokazivanjem na ognjište gdje bi se vještice, prema predaji, znale okupljati. Simbolička vrijednost vatre je iznimno snažna te je imala gotovo sakralnu vrijednost jer je u simboličkom smislu utjelovljivala obitelj, gostoljubivost i život. ${ }^{9}$

Ivan Lovrić je još u 18. stoljeću opisao prigodu u kojoj se pripovijedaju priče i okolnosti u kojoj nastaju:

»Zato zimi, napunivši dobro trbušinu, ponajviše mnogo sjede, te praveći polukrug oko ognjišta, gdje se griju, naizmjenično pripovijedaju prljave pričice, ali ne zaboravljaju ni istinite, koje se tiču povijesti našeg naroda.«10

Ognjište je u pripovjednoj praksi kazivača česta lokacija kazivanja priča. Osim toga, u starinskoj arhitekturi kućanstva ognjište zauzima poseban prostor koji se koristi za sve kućanske poslove, ali isto tako i za primanje gostiju. Ognjište je mjesto u kućanstvu gdje se često okupljaju muški članovi kuće kao i njihovi prijatelji i gosti. Obitavanje oko ognjišta karakteristično je za stanovnike ruralnih područja i čini svojevrsni kulturološki specifikum. Osim primarne kulinarske i toplinske funkcije, vatra na ognjištu služila je i kao centar pozornice oko koje se oblikuje usmenoknjiževna kazivačka situacija. Kazivači koji gestama, mimikom, glumom i pokazivanjem iznose usmenoknjiževni sadržaj često u svoje kazivanje uključuju prostor i predmete koji ih okružuju čineći time realan prostor $\mathrm{u}$ kojem se nalaze novom mizanscenom pomoću koje recipijenti mogu postati dio ispripovjeđene stvarnosti. ${ }^{11}$ Sjedenje i pripovijedanje oko vatre i ognjišta uvjetovano je prirodnim procesima koji potiču čovjeka da se približi vatri na ognjištu i ondje provede gotovo najveći dio vremena dok obitava u kući. Odnos konteksta prostora i situacije opisuje Frano Ivanišević:

»Kad se uneda vrimenu pa ne mo'š izać ni u polje ni prid kuću, sastaje se svit osobito zimi po ognjenican, grije dlane uz oganj, puši se, razgovara, inglendi se mlađarija i zabavlja. $\ll^{12}$

Sličnu kazivačku situaciju navodi i Luka Ilić Oriovčanin za slavonski kraj:

»Zimsko vrěme, osobito pak duge večeri sprovadja slavonska mladež obojeg spola na Prelu, koje je jedna izmedju najvećih zimnih zabavah... (...) Skupivša se

\footnotetext{
${ }^{9}$ Usp. Raffaela SARTI, Živjeti u kući. Stanovanje, prehrana i odijevanje u novovjekovnoj Europi (1500.-1800.), Zagreb, Ibis grafika, 2006, 111.

${ }^{10}$ Ivan LOVRIĆ, Bilješke o putu po Dalmaciji opata Alberta Fortisa $i$ život Stanislava Sočivice, Zagreb, Izdavački zavod Jugoslavenske akademije, 1948, 81.

${ }^{11}$ Usp. Maja BOŠKOVIĆ-STULLI, Usmeno pjesništvo u obzorju književnosti, Zagreb, Nakladni zavod Matice hrvatske, 1984, 385.

${ }^{12}$ Frano IVANIŠEVIĆ, Poljica. Narodni život i običaji, Priko, Društvo Poljičana »Sveti Jure«, 2006, 413.
} 
ženska mladež medju pěvanjem raznih pěsamah, prede; dočim mužkarci jedan drugom ili pripovědaju što im se priko dan u šumi sgodilo... «13

Posebno je zanimljiv lirski obojen opis Frane Ivaniševića kada opisuje kazivačku situaciju u Poljicima u dalmatinskoj Zagori:

»Zima je ljuta, prsti opadaju s ruke. Urliče bura po kućan i dvorištin, a mećava siplje snigom plastašen ka' lišćen. Svak se pozatvorija u kuću - suton sa zemlje u'vatija led priklopija, sva kućna čeljad okupila se na kominu uz oganj. Domaćica nastivala pun naramak cipotina, vatra se rasplancala, svak pritiče mrzle ruke i dlane pa se grije... 'Ko će dugu noć prispavat, daj ti, Ivane, gusle, eto ji' povr' ambara, u koga je tanko i složito grlo, neka zapiva jednu junašku jedan od vas mlađi', naredi domaćin. Svak se ominje (oteže), guslača valja umolit, a kad počne, jedva ga moreš zaustavit. Niki valjani guslači po cilu debelu uru naviju gudalon i pripivaju pismu od megdana i junaka. (...) Svak u kući, malo i veliko, sluša ga pomljivo, ne će niko živ ciknut, muškići pušu lulu, a ženske predu kudilju ili pletu u rukan. Kad guslač priduši i opočine, anda slušaoci begenaju ili kudu junaka, divojku, o komu se piva. ${ }^{14}$

Vidljiva je u ovom opisu praktična funkcija ognjišta i vatre uz koju se ukućani griju. U nekim dijelovima Europe je zabilježeno da su ukućani spavali oko ložišta ili uz kamin te uza nj primali goste i putnike. ${ }^{15}$ Osim toga, vidljiva je i svrha izvođenja usmene književnosti u kojoj dosada postaje pokretač iznošenja usmenoknjiževnog izričaja na zadovoljstvo male zajednice.

Sigurnost i zaštita koju nudi kućanstvo s upaljenom vatrom na ognjištu uvjetovali su izbor kazivanja koja su se prenosila. Navedene kazivačke situacije su specifične jer je opisana atmosfera vatre koja gori u kućanstvu, u interijeru i čini prostor zaštićen od vremenskih neprilika. Stoga je korpus predaja koje se pripovijedaju uz ognjište uvjetovan prostorom u kojem se sudionici osjećaju sigurno. Ponekad, iz čiste zabave i osjećaja sigurnosti, djeca zatraže da se pričaju priče koje imaju funkciju ulijevanja straha. Osobnim iskustvom sam svjedočio da se strašne predaje lakše primaju i slušaju uz ognjište nego uz vatru na otvorenom. Interijer domaćinstva u kojem se živi pruža utočište u kojem se recipijent može osjećati zaštićeno ne samo objektom u kojem živi, nego i bliskošću prisutnih članova obitelji. U takvim kazivačkim situacijama u kojima se pripovijedaju »strašne priče« perceptivna razlika između interijera i eksterijera ima značajnu ulogu. Dok je recipijent okružen ukućanima u interijeru, sve što ga okružuje čini sigurnost i zaštitu. No kada iz tog prostora iziđe na otvoreno, perzistencija predaje je iznimno jaka, a noćni eksterijer ne pruža nikakvu zaštitu koju je maloprije imao. U takvim situacijama bi strah prevladao i recipijenti bi se borili s vlastitim osjećajem straha i često bi utrčavali nazad u prostoriju

\footnotetext{
${ }^{13}$ Luka ILIĆ ORIOVČANIN, Narodni slavonski običaji. Sabrani i popisani po Luki Iliću Oriovčaninu, Novska, Gradsko poglavarstvo grada Novske, 1997, 214.

${ }^{14}$ Ivanišević, Poljica..., 427.

${ }^{15}$ Usp. Sarti, Živjeti u kući..., 108.
} 
gdje se pripovijeda. Utrčavši s užasom na licu izazvali bi smijeh kod prisutnih. Dvadeset godina nakon takvog iskustva imao sam priliku razgovarati o kazivačkim situacijama sa sudionicima s kojim sam slušao takve predaje i dolazim do zaključka da im je strah pri uriniranju na otvorenom, nakon pripovijedanja »strašnih priča«, jedno od mučnijih iskustava vezanih za strah. Doživljaji stra-

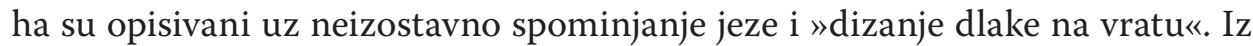
navedenog iskustva se može zaključiti da promjena prostora uvjetuje doživljajnost predaje i osjećaj sigurnosti.

Osim toga, pri paljenu vatri noću u eksterijeru, u brdima, kod crkve i sl. sama gestikulacija sudionika odražava njihovu spremnost odgovora na prijetnju iz mraka. Sudionici u razgovoru okrenuti su prema vatri i ne postoji izravan hijerarhijski obrazac po kojem se oni ponašaju. Paljenje vatre noću, na otvorenom je često praktičnog karaktera i uvjetovano tamom i hladnoćom. Takvi uvjeti ne izazivaju ugodu te vatra ima funkciju osiguravanja prostora od hladnoće, tame i potencijalnih životinjskih predatora. Paljenjem vatre bilo gdje na otvorenom stvara se specifičan mikroprostor koji evocira sigurnost doma. No isto tako se stvara i univerzalan opći prostor kojem je centar vatra, prostor u kojem se svi sudionici mogu osjećati zaštićenije i intimnije. Vatra ima funkciju oplemenjivanja prostora prema osjećaju sigurnosti koje nudi interijer kućanstva u kojem je pojedinac kroz prošlost navikao provoditi dio života. Međutim, tama koja okružuje rubni prostor onoga koga vatra osvjetljava postaje još nepoznatija i dalja. U razgovoru sa sredovječnim lovcima u brdima doline Neretve čuo sam da im vatra noću u brdu ometa dobar vid tako da im je tama još veća, a hladnoća koju osjećaju na svojim leđima ulijeva osjećaj nesigurnosti. Uočava se da $\mathrm{u}$ pripovjedačkim situacijama u interijeru postoji pripovjedački autoritet koji iznosi kazivanja u kontinuitetu, dok se uz vatru u eksterijeru sudionici unakrsno nadopunjuju u pričanju te se stječe dojam da je interijer odraz privatnog prostora i privatnog odnosa između kazivača i recipijenata dok se na otvorenom sudionici ponašaju poput sugovornika.

$\mathrm{U}$ takvim kazivačkim situacijama na otvorenom sudionici se izmjenjuju $\mathrm{u}$ kazivanjima i vrše obostrani prijenos informacija, gdje su sudionici u ravnopravnijem položaju. Primjer podređenijeg položaja u kazivačkim situacijama imao sam u jednom kućanstvu gdje je vlasnica kućanstva pripovijedala gotovo trideset minuta, kada je u prostoriju ušla njena rodica i susjeda. Ušavši u kuću gotovo neprimjetno je pozdravila i sjela postrani. Nakon desetak minuta ona je neverbalnim znakovima pokazivala potrebu da se uključi u razgovor, no zbog toga što je bila u posjetu, puštala je prednost pripovijedanja domaćici, ubacivši se katkad komentarom - kako i ona zna ponešto o temi o kojoj se pripovijeda. Kasnije me je pozvala do dođem kod nje da mi može mnogo toga ispričati iz vlastitog iskustva. Iz navedenog zaključujem da se kućanstvo doživljava kao privatan prostor domaćina te da se primat u pripovijedanju prepušta domaćinu. Različito od osjećaja privatnog prostora kućanstva, eksterijer se doživljava 
kao zajednički prostor u kojem je sudioništvo u pripovijedanju u ravnopravnijem odnosu. Kada se pripovijeda oko vatre u eksterijeru za pretpostaviti je da se sudionici susreću na neutralnom prostoru, daleko od svojih domova te se time stvaraju uvjeti za ravnopravniji komunikacijski odnos koji ne trpi pripovjednu predominaciju domaćina. Iz tog odnosa intimnog i javnog prostora proizlaze i tipovi predaja. Primjerice, kada se pripovijeda u intimi i sigurnosti doma, mogu se čuti kazivanja o drugim obiteljima i njihovim prošlostima otkrivajući ponekad i intimne tajne pojedinaca. Takav oblik pripovijedanja na otvorenom, gdje se susreću pojedinci iz različitih obitelji, neće biti poželjan te će se autocenzura provoditi intenzivnije $u$ želji da se ne izgovori nešto što pripada privatnom životu sugovornika ili njegovih bližih ili daljih članova obitelji i rodbine.

Osim ognjišta uz upaljenu vatru, pripovijedanje je zastupljeno i na raznim drugim mjestima. Obično su to otvoreni prostori poput brda, šuma, livada, obala rijeka, bunara, ulica, guvna itd. ${ }^{16}$ Pjesme se pjevaju po brdima, poljima i drugim otvorenim prostorima na ispaši, na moru, u planini. Prema bilješkama iz rukopisne zbirke Maje Bošković-Stulli, kazivač Niko Roko svjedoči o pričanju priča oko kamina, ložišta i na sijelu:

»Ljudi me slušaju, ima ljudi što ih jako zanima. A i mlađe, zanima dosta i mlađe (...) Pa ovako, znate, kad bi se sastali večer na sijelu, kad bi pričali (...) Ovako večer je običaj, kao u nas ovdi po selima, ka(d) su duge noći, skupu se ovi svi susjedi ovdi u mene u komin, kužinu i onda večer pričamo. «17

Slična pripovjedačka situacija je i u drugim krajevima. Primjerice, u Sinjskoj krajini je također poznata praksa pripovijedanja uz ognjište i vatru: »Pa tako bi pripovidali uvečer kad bi sidili (...) Ovako okolo komina pušili bi, nije se bilo na radovin, nije bilo zaposleno. ${ }^{18}$ Druga kazivačica, Anica Matić iz Brgata kod Dubrovnika svjedoči o praksi pričanja priča: »Ovako uveče kod vatre. Dođu djevojčice, vrsnice moje male, dođu i susjede, mlađe žene, pa slušaju. «19 Opisujući pripovjedačke okolnosti u Poljicima, Frano Ivanišević također navodi praksu pričanja oko vatre uz praksu pripovijedanja na putu ili za stolom, zimi uz večeru ili na putu, kako bi brže prošlo vrijeme. ${ }^{20}$

Gotovo identične prilike neinduciranog pripovijedanja razvile su se i kod kazivača donjoneretvanskog kraja. Budući da je autor ovog rada i sam bio svjedok ovakve prakse pripovijedanja od ranih godina djetinjstva, može potvrditi da prilikom recepcije predaja s fantastičnim elementima podsvjesno interferira s pojedincem te se vrlo lako uspostavlja intiman transmisijski odnos između predaje i recipijenta. Sudjelovanje u izvođenju usmenoknjiževnih narativa oko vatre, a posebice oko ognjišta, vezano je uz mističan doživljaj vatre i pojačava-

\footnotetext{
${ }^{16}$ Usp. Ivanišević, Poljica..., 414.

${ }^{17}$ Bošković-Stulli, Žito posred mora..., 26-27.

${ }^{18}$ Isto, 312.

${ }^{19}$ Isto, 26-27.

${ }^{20}$ Usp. Ivanišević, Poljica..., 433.
} 
nje perceptivne moći slušatelja i samog kazivača. Dojam koji ostavljaju priče i pjesme izgovorene uz vatru u mnogočemu popularnost duguju i percepciji vatre kao simbola sa svim svojim antropološkim i psihološkim vrijednostima koje čovjek baštini u svojoj svijesti. Svijest o važnosti vatre od početka evolucije ljudske kulture do suvremenosti manifestira se i u primjeni vatre u godišnjim ritualima, ali i u obogaćivanu perceptivnih obrazaca društvenih djelovanja u okupljanjima gdje se izvode usmenoknjiževne tvorevine. ${ }^{21}$ Odnos čovjeka prema vatri očituje se u svojevrsnoj ritualizaciji paljenja i održavanja plamena, pa čak i u situacijama gdje se inicijacijski odnosi prema vještini paljenja vatre.

»Sam čin paljenja vatre i okupljanja oko nje proizlazi iz iskonskog uzbuđenja koje njezina toplina, plamen i način sagorijevanja izazivaju kod svakog pojedinca. Ta opčinjenost plamenom i danas je vrlo očita ako se pažljivo promatra ponašanje ljudi u raznolikosti dodira s vatrom. $\ll^{22}$

Neće se pogriješiti ako se kaže da je vatra osnaživač dojma usmenoknjiževnih narativa, posebno zbog izgleda mizanscene i kontrastnih odnosa svjetla i sjene na licima okupljenih sudionika. Atmosfera koja se ostvaruje vatrom izvanredno je pogodna pripovijedanju i dojmu koji narativ ostavlja na slušatelje. Razumljivo je da je okupljanje oko vatre događaj koji podrazumijeva noćnu atmosferu koja, posebno zimi, predstavlja svijet obavijen tamom, hladnoćom, tajnama, nemirom, strahom i nevidljivim pojavama. Plamen i vatra pružaju u takvoj noći sigurnost i zaštitu - svojevrsnu suprotnost hladnoj noći i svemu što čovjeka prošlih vremena uznemiruje. U tom kontrastivnom mikrokozmosu intimne atmosfere i otvorenog mračnog svijeta noći razvija se vrlo pogodno »tlo« za prakticiranje usmene književnosti. Općepoznato je da pojedini narativi gube na vrijednosti ako budu ispričani u nepovoljnim uvjetima ili u okolnostima koje odvlače pozornost recipijenata. No, kazivanja izvan prostora koji grije vatra s ognjišta nisu manje vrijedna, ona se jednostavno prilagođavaju situaciji i kontekstu u kojem se nalaze. Tako je korpus priča o nadnaravnim bićima i pojavama čest u pripovijedanju oko vatre, dok su drugi oblici pripovijedanja i pjevanja karakterističniji za rad u polju ili susrete mladih na sijelima, proslavama ili ispašama. Jedan od razloga za to je i u doživljaju ognjišta kao mjesta od posebne simboličke i mistične vrijednosti. ${ }^{23}$ Pripovijedanja koja se odvijaju danju i na otvorenim prostorima sadrže elemente pričanja iz života i poprimaju osobine razgovora u kojem se iznose spoznaje i mišljenja o raznim svakodnevnim djelatnostima i socijalnim interakcijama. Noćna pričanja uz vatru zahtijevaju drugačije narativne konstrukte te se izvođačka praksa potiče zajedno s odabranim korpusom narativa koji prelaze u prave usmenoknjiževne

\footnotetext{
${ }^{21}$ Usp. Branko ĐAKOVIĆ, Igre oko vatre. Prilog etnološkim istraživanjima o vatri, Samobor, Meridijani, 2011, 10.

${ }^{22}$ Isto, 12.

${ }^{23}$ Usp. Aida BRENKO, Mirjana RANDIĆ, Marija ŽIVKOVIĆ, Vatra=Fire, Zagreb, Školska knjiga, 2011, 55-56.
} 
tekstove. Bez obzira na vremensku i prostornu odvojenost od jedne zajednice do druge, uočava se da je takav obrat u selekciji građe u dnevnom i noćnom pripovijedanju oko vatre sociološka kategorija vlastita različitim zajednicama. Pri proučavanju antropoloških obrazaca uz vatru Ju/'hoan Bušmana južne Afrike Polly W. Wiessner uočava da se fokus konverzacije u večernjim satima mijenja $\mathrm{s} » d n e v n e$ konverzacije« te se pozornost usmjerava s ekonomskih i socijalnih konverzacija na one koje sadrže priče koje su za zajednicu zabavne i uzbudljive. ${ }^{24}$

U pripovijedanju sudjeluju muškarci i žene, posebno stariji koji su izvještili pripovijedanje te se kvalitetan i vješt pripovjedač cijeni zajedno s korpusom priča koje dijeli sa zajednicom. ${ }^{25}$ Wiessner zaključuje da su priče u lovačkosakupljačkim društvima bile originalan društveni medij. ${ }^{26}$

Osim toga, i u današnjim vremenima, prije uskrsne i božićne polnoćke, stanovnici sela u dolini Neretve pale vatre pored crkve i okupljaju se oko nje pripovijedajući razne životne situacije, počevši od razmjene obiteljskih informacija do prisjećanja prošlih vremena i ponekih anegdota iz života. Duljina trajanja usmenoknjiževne forme također je uvjetovana kontekstom u kojem nastaje ili se prenosi. Tako konteksti i prostori usmenoknjiževne komunikacije mogu uvjetovati usmenoknjiževni oblik i pripovjedni repertoar.

Bez obzira na mnoga mjesta koja su pripovjedne lokacije, može se zaključiti, kako kazivači navode, da se vrlo često priča oko vatre, odnosno na ognjištu ili oko ognja. Ta se lokacija ističe više od ostalih i predstavlja pravi je izvor za okupljanje ljudi i pričanje priča. Korpus tema i sižea koji se prenose od kazivača na recipijenta oko vatre je golem i nije ograničen samo na jedan tip predaja nego se ostvaruje široko, putem gotovo svih priča. Zanimljivo je da ognjišta i vatre privlače različite osobe koje sudjeluju u transmisijskom procesu pa se tu mogu naći stari i mladi, muškarci i žene. Iz svega navedenog, može se primijetiti da ognjište zauzima središnju ulogu u domaćinstvu pa tako i u svjedočenju pripovjedne prakse iz prošlosti doline Neretve. Slično je i u drugim krajevima dalmatinske Zagore i Zabiokovlja. Naime, ognjišta su prema svojoj funkciji i namjeni kućna okupljališta, gdje domaćinska obitelj i gosti sjede oko vatre na ognjištu. Frano Ivanišević, opisujući domaćinstvo Poljica navodi da i u vrijeme

\footnotetext{
${ }^{24}$ Usp. Polly W. WIESSNER, Embers of society. Firelight talk among the Ju/'hoansi Bushmen, Proceedings of the National Academy of Sciences of the United States of America, 111 (2014) 39, 14027-14035, 14029; https://doi.org/10.1073/pnas.1404212111.

${ }^{25}$ »Both men and women told stories, particularly older people who had mastered the art. Camp leaders were frequently good storytellers, although not exclusively so. Two of the best storytellers in the 1970s were blind but cherished for their humour and verbal skills. Stories provided a win-win situation: those who thoroughly engaged others were likely to gain recognition as their stories travelled. Those who listened were entertained while collecting the experiences of others with no direct cost. Because story telling is so important for remembering and knowing people beyond the camp, there is likely to have been strong social selection for the manipulation of language to convey characters and emotions « (isto).

${ }^{26}$ Usp. isto, 14032.
} 
odsutnosti ukućana oko ognjišta i dalje ostaju predmeti na kojima se sjedi: »Naokolo komina namišćeni su banci, stoci i katrige za sidit i grijat se uz oganj.« ${ }^{27}$

Osim toga, ognjište je i klasičan topos u predajama o vješticama cjelokupne hrvatske usmenoknjiževne prakse. Iz velikog korpusa predaja čija je tema opisivanje naravi i djelovanja vještica, može se izdvojiti nekoliko osnovnih toposa koji jednako vrijedno funkcioniraju u tim predajama. Tako, pri pripovijedanju o vješticama kazivači koriste lokacije kao što su raskrižje, kuća, ognjište, šuma i stablo oraha. Promatrajući važnost ognjišta kao lokacije u predajama uočit će se njegova višestruka funkcija. Često u predajama vještice skrivaju svoj dragocjeni ćup/vrč/posudu sa smjesom, a često je u predajama to mast, kojom se trebaju namazati da bi uspješno premostili daleke prostore. Ognjište se u hrvatskim usmenoknjiževnim predajama o vješticama očituje kao mjesto na kojemu »demoletačice« čuvaju mast za letenje..$^{28}$

»One ti imaju to svoje te, dogovore se unda one iđu pa tamo čine vijeće svoje. Tribaju one, kaže, četrdeset dana ne umivat se i ne češljat i ne, nokte ne rizat’ i ići to večer mlatit, mlatit, kaže po ognjištu rasprećat ognjištu, pa mlati` po tomu:

- Izađi crni lončiću!

Pa se, kaže, sve s` otizin po glavi mazat.

- Izađi crni lončiću, donesi mi krila da odletin u pulju pod oras, da ne udren ni o' drvo, ni o' kamen! « ${ }^{29}$

I u drugim usmenim predajama Dalmacije ognjište se spominje u gotovo istim funkcijama. Posudu se skriva ili odmah uz ognjište ili unutar samog ognjišta. Posuda se pronalazi ili se posredstvom magične formule stvori na ognjištu, a mast u njoj služi kao medijator letenja na vještičje sastanke. Vrlo često su se, prema vjerovanju, mazale prije leta; katkad njome mažu i štap na kojem lete. »Isto tako taj štap mažu nekom gadnom pomasti priređenom prema uputi lukavog demona. Ta se pomast pravi od određenog dijela tijela još nekrštene djece... $\aleph^{30}$ Ognjište vrši funkciju polazišne pozicije s koje vještice, po predaji, putuju na druga udaljena mjesta. Ognjište kao centralni dio starinskih kućanstava zauzima važnu ulogu u prijenosu vještica na željene destinacije.

Naravno, posredstvom prijenosa informacija putem predaje i posebno posredstvom vjerovanja $u$ istinitost informacija iz predaja, starije žene su obavljale apotropejske čini da bi se zaštitile od dolaska vještica posredstvom ognjišta. Draga Vekić iz Borovaca, posredstvom vjerovanja u istinitost predaje, radila je apotropejski čin križa na ognjištu. Podignuvši »sačuru« i ispečeni kruh s

\footnotetext{
${ }^{27}$ Ivanišević, Poljica..., 70-71.

${ }^{28}$ Usp. Suzana MARJANIĆ, Vještičje psihonavigacije i astralna metla u svjetovima hrvatskih predaja kao (mogući) aspekti šamanske tehnike ekstaze (i transa), Studia ethnologica Croatica, 17 (2005) 1, 111-169, 137.

${ }^{29}$ Kazivala Ivka Jerković. Zapisao Denis Vekić, 12. kolovoza 2013. u Metkoviću.

${ }^{30}$ Vladimir BAYER, Ugovor s davlom. Procesi protiv čarobnjaka u Evropi a napose u Hrvatskoj, Zagreb, Informator, 1982, 361.
} 
ognjišta, vratila bi žeravicu i pepeo natrag na ognjište i ožegom napravila jednakokračni križ preko cijelog ognjišta. Na upit zašto to radi odgovorila bi da se na taj način štiti od vještica te da se zbog križa one ne mogu približiti ognjištu ni preko njega putovati i činiti štetu kući kojoj ognjište pripada. Nadalje, rekla je da bi vještice, ako ne bi naišle na križ, »sletile na ognjište i rasprpale žeravicu po cijelom kućanstvu«, te da bi napakostile ljudima koji tu žive. ${ }^{31}$ Iz navedenog se može vidjeti da ognjište, prema predajama i vjerovanju, funkcionira kao translokator vještica i kao centralno mjesto početka vještičjeg putovanja.

Zbog života u urbanoj sredini, te zbog izostanka otvorenog ložišta u kućanstvima, inducirane kazivačke situacije u istraživanju nisu se odvijale na autentičnim lokacijama kao što je ognjište. Umjetno stvorena kazivačka situacija nije spriječila kazivače jer su i sami bili svjesni da se kazivanje obavljalo na različitim mjestima, a ne samo i isključivo pored otvorenog ložišta. Ognjište u ovoj predaji postaje nova lokacija koja se unosi u predaju kao mjesto radnje. $\mathrm{Na}$ taj način recipijenti koji su okupljeni oko ognjišta usvajaju novu sliku prostora u kojem obitavaju. Ognjište je do tog trenutka bilo mjesto sigurnosti i ugode, a nakon predaje u kojoj vještice putuju ognjištima nova funkcija te lokacije daje kompleksniju sliku svijeta u kojem se nalaze. Do tog trenutka je ognjište bilo neokaljano mjesto kućanstva, dok se u novoj ulozi pretvara u mjesto iz predaje. Time je vjerodostojnost pripovijedanja predočena u opipljivoj prisutnosti opasnosti koja vreba iz najsigurnijeg kuta domaćinstva te čini direktnu sponu između realnog i fantastičnog. Nakon iskustva slušanja navedene predaje recipijenti se moraju suočiti s nevidljivim granicama između realnog i fantastičnog te se time involviranost $u$ istinitost predaje pojačava te iz involviranosti proizlazi i običajna praksa ucrtavanja simbola na ognjište.

Atmosfera u kojoj se pripovijedaju predaje na ognjištu osigurava intimnost prostora i odnosa sudionika. Kao što je već navedeno, intiman prostor ognjišta omogućuje da se istaknu pojedini talentirani kazivači. Tako ognjište postaje opći prostor za pripovijedanje usmenoknjiževnih oblika koji u sebi nose visoku umjetničku kvalitetu. Kao i u drugim performativima, ognjište postaje scena koja se stapa s prostorom za recipijente. Granica između izvođača i recipijenata gotovo i ne postoji te je slušanje izvođača ujedno i sudjelovanje u prijenosu usmenoknjiževnog sadržaja jer se recipijenti trude zapamtiti izvedbu u onom obliku u kojem je nastala. Tako pri novom izvođenju usmenoknjiževnih oblika nekadašnji recipijent postaje izvođač te se služi sličnim postupcima iskorištavanja prostora i predmeta oko ognjišta da bi što vjernije rekreirao onu verziju koju smatra najuspješnijom .

Korištenjem predmeta koji se nalaze u prostoriji s ognjištem izvođač može podignuti razinu vjerodostojnosti i uvjerljivosti kazivanja. Stoga je traženje poveznice između ispričanih događaja i prostora u kojem se događa kazivanje po-

${ }^{31}$ Događaj se zbio sredinom devedesetih godina dvadesetog stoljeća u selu Borovci u dolini Neretve. Svjedočio i zapisao Denis Vekić 2007. godine u Metkoviću. 
stupak koji može probiti prostornu granicu koju recipijenti percipiraju. Primjer takvog djelovanja je kazivačevo pijenje vina iz »bukare« dok se pripovijeda o nekome koji u tom trenutku radnje pije vino. Tako je jedan kazivač pričao anegdotu o gostu koji je često dolazio $\mathrm{k}$ jednom domaćinu i dosađivao mu nekoliko večeri pijući velike količine vina iz domaćinove bukare. Domaćin je zato nakon otpijanja vina stavljao bukaru ispod svog tronošca da gost ne bi sve popio. Kazivač je, imitirajući situaciju, postavio čašu ispod svojeg tronošca te na taj način odglumio situaciju učinivši je toliko živom da su recipijenti na trenutak bili sudionici situacije, a ne samo pasivni slušatelji nečemu što se dogodilo.

Osim toga, ognjište je svim sudionicima poznat topos iz spomenutih predaja o vješticama u kojima se priča o masti koju vještice koriste za letenje, a čuvaju je u lončiću pored ognjišta. Isto tako, interijer ognjišta iz vjerovanja o vještičjem letu preko ognjišta postaje oživljeni topos iz predaje koji nije dio fikcije nego dio stvarnog života te prostor u kojem se nalaze recipijenti gubi onu granicu sigurnog područja koje ne može probiti ni opasnost iz predaje. Upravo suprotno, ovakvim postupkom pričanja o realnoj lokaciji koja postaje narativna stalna lokacija, recipijenti imaju priliku živjeti tu predaju i involvirati se u dokazivost istinitosti pripovijedanja. Time se ognjište, kao objektivan prostor sa svojim praktičnim funkcijama, transformira u scenu iz predaje.

\section{U gostionici}

U narativnom procesu usmene i pisane književnosti gostionice, krčme, kavane i kafići imaju slično mediološko značenje te njihova funkcija odražava ne samo stvarnost u kojoj se one manifestiraju, nego čine i mjesto gdje se formira kolektivno mišljenje o stanovitim pitanjima. Može se reći da se u suvremenosti gradsko dvorište, trg i gostionica mogu usporediti s onim što su u antici bili akropola i rimski forum. Emisijska pripovjedna djelatnost u gostionicama je aktivnost koja je u sprezi s tim mjestom jer priroda gostionice podrazumijeva međudruštvenu interakciju i komunikaciju koja, osim puke izmjene informacija, može iznjedriti i fabulative oblikovane prema nekim narativnim žanrovskim karakteristikama. Gostionice kao mjesta odvijanja radnje i kao mjesta nastanka narativnih konstrukcija su zanimljiva za istraživanje jer se njihova funkcija i uloga mogu pratiti ne samo u pisanoj književnosti već i u usmenoj književnosti, naravno u siromašnijem obliku nego što to nudi pisana književnost. Gostionice kao književni toposi su do sada već proučavane, no može se reći da bi se o njima moglo još mnogo toga istražiti. Svaka važnija gostionica i prenoćište u prošlosti imala je velik kamin ili ložište vatre prvenstveno radi praktične funkcije grijanja, no osim te, bila je tu i emisijska narativna funkcija koja bi se razvijala kada bi se gosti okupljali oko vatre. Upravo taj kontekst pripovijedanja oko vatre, koji je obrađen u prethodnom poglavlju, smješta vatru kao univerzalni pripo- 
vjedački »potpaljivač« upravo pod krov gostionice i/ili krčme čineći tako spoj dvaju čestih mjesta pripovijedanja i razmjene informacija. Vatra u krčmi ima jednaku funkciju kao bilo koja vatra oko koje se sudionici razgovora okupljaju da bi razgovarali i u jednom trenutku stvorili potencijalnu kazivačku situaciju važnu za proučavanje u okvirima usmene književnosti.

Mjesta susreta društva gdje se ostvaruje informacijska transmisija prepričavanjem i pripovijedanjem čini navedene prostore aktivnima u toj transmisiji. Čak i u suvremenosti ne nedostaje primjera izvođenja usmene književnosti u javnom prostoru krčme. Jedan takav događaj navodi Nenad Perković u kolumni gdje opisuje svoj razgovor s Vladimirom Dodigom Trokutom, likovnim umjetnikom i pjesnikom:

"Sreli smo se na ulici. Ušli u prvu krčmu koju smo vidjeli. Bila je to, danas zatvorena, Stara ciglana na uglu Klaićeve i Kačićeve ulice u Zagrebu. Trokut je započeo jedno od svojih podugačkih kazivanja, a ja sam preuzeo ulogu onoga koji intervjuira: minimalnim intervencijama poticao sam nove i nove odgovore, koji zapravo i nisu bili odgovori na pitanja, već priče same, kao što ni pitanja nisu bila prava pitanja. Seansa je trajala više sati, i posebno je zanimljivo ozračje, kao i mizanscena.

Nije to bio privatan razgovor dvojice prijatelja u javnom prostoru, kakve smo inače znali voditi. U prostoru se kreirala publika. Lokalni pijanci i drugi posjetitelji pomalo su ostavljali svoje razgovore, prostor se utišao, pozicije sjedenja i konstelacija gostiju prearanžirala se u gravitaciji prema kazivaču. Sjedili smo za šankom, pa se i pipničar, zajedno s najtvrdokornijim kronerima nalaktio da bolje čuje, i sve sporedne aktivnosti u lokalu su zamrle, ili su se svele na minimum. Ako bi šanker uključio bučni aparat za kavu netko bi nervozno reagirao ušutkavanjem jer mu je buka omela pozornost dok prati kazivanje. Trokut ni $\mathrm{u}$ jednom trenutku, kao da je u transu, nije pokazao da je svjestan zbivanja u okolišu, potpuno usredotočen na ono što govori.

Tu nije kraj zanimljivostima. Nakon isteka petog sata, pred zatvaranje, dogovorili smo se za nastavak sutradan. Bio je to sasvim privatan dogovor između nas dvojice. Pojavili smo se na istom mjestu u zakazano vrijeme, a navlas ista mjesta za šankom su nas čekala, čak je i većina jučerašnjih posjetitelja opet bila tu. Neki bi po svim kriterijima spadali u standardni opis 'inventara', što je obilježje svake lokalne birtije, no neki su, bez svake sumnje, došli vidjeti, no prije svega čuti, drugi dio zakazanog 'performansa'. Neki su doveli i prijatelja.« «2

U ovoj situaciji sama kazivačka situacija prepričana je jednostavnim narativnim tehnikama. Nenad Perković je u ovom kratkom pripovijedanju o pripovjedaču iznio osnovne karakteristike neinducirane i inducirane kazivačke situacije koja je u početnoj fazi funkcionirala kao dijalog dvaju sudionika, no ubrzo je postala monolog $\mathrm{s}$ afirmativnom slušalačkom recepcijom. Ovaj opis kazivačke situacije ukazao je na važnost onog vještog kazivača koji umije deskriptive i narativne konstrukte dovesti do savršenstva. Time je njegova važnost usmjere-

\footnotetext{
${ }^{32}$ Nenad PERKOVIĆ, Začitavanje o zapričavanju, (04.03.2015) http://www.booksa.hr/kolumne/ zacitavanje/zacitavanje-o-zapricavanju (02.06.2018).
} 
na ne na sadržaj koji iznosi nego na način koji taj sadržaj iznosi. Recipijenti su prepoznali njegovu vještinu posredstvom vlastitih individualnih umjetničkih receptora koje kod sebe ne bi mogli prepoznati niti opisati. Ali, slušajući kazivača u njima se osjećaj za umjetničku vrijednost usmenoknjiževnog oblika probudio te vrlo brzo pretvorio u kritičku sposobnost kojom mogu procijeniti vrijednost kazivanja. Time se ostvaruje važan koncept postojanja specifičnih usmenoknjiževnih oblika i primjera u kojem recipijenti procjenjuju njegovu vrijednost te ga svojim daljnjim distribuiranjem održavaju »živim«.

$\mathrm{Na}$ ovom primjeru vidljivo je da emisija usmenoknjiževnog sadržaja često nastaje spontano i da se, pomoću nadarenog pojedinca, informativnost i formulacija izričaja može prenijeti na sve prisutne sudionike. Krčma je u urbanim sredinama suvremeni kontekst tradicijskog pripovijedanja usmenoknjiževnih narativa i kao takva postaje nov prostor transmisije informacija jedne manje, koherentnije zajednice koja ju posjećuje. Stoga je, pri proučavanju emisije i recepcije usmene književnosti, zanimljivo promatrati gostionicu u kontekstu prostora koji funkcionira kao kulturno raskrižje i informativno središte kroz koje se manifestiraju odnosi duha i svjetonazora nekog razdoblja te kao kulturno i diferencijacijsko mjesto kulturnih preferencija.

Poznato je da pisana književnost prepoznaje društvenu važnost gostionice i prenoćišta te ih uvrštava u svoje narative predočujući ih kao društveni mikrokozmos koji utječe na kulturološki makrokozmos. Proučavajući odnos usmenoknjiževne predaje i nastanka ugostiteljskog objekta u Sarajevu s imenom »4 sobe gospođe Safije« nastao je rad »Od Lutvine kahve do 4 sobe gospođe Safije - između legende i autentičnosti« koji je objavljen u časopisu Motrišta. ${ }^{33}$ Taj specifičan odnos između predaje i njenog potvrđivanja i oživljavanja gradnjom objekta koji će po svojoj funkciji i specifičnostima biti refleksija predaje govori o novim kategorijama odnosa između predaje i suvremenosti. Gostionica je zaradila svoje uvaženo mjesto kao književni topos upravo kroz primjere djela kao što su »Canterburyjske priče « ${ }^{34} »$ Tri mušketira « Alexandrea Dumasa S gostionicom »K slobodnom mlinaru,$_{,}^{35} »$ Križari« Henryka Sienkiewicza s krčmom »K divljem biku«, ${ }^{36} » K c ́ i$ Lotrščaka« Marije Jurić Zagorke s bezimenom krčmom, ${ }^{37}$ »Travnička hronika« Ive Andrića i krčme »Lutvina kahva «. ${ }^{38}$ Više o tim aspektima i odnosima se može pročitati u spomenutom radu. ${ }^{39}$

\footnotetext{
${ }^{33}$ Vanda BABIĆ, Denis VEKIĆ, Od Lutvine kahve do 4 sobe gospođe Safije - između legende i autentičnosti, Motrišta - časopis za kulturu, znanost i društvena pitanja, 71-72 (2013) 29-35; http://www.maticahrvatska-mostar.ba/images/pdf/motrista/motrista_71-72.pdf.

${ }^{34}$ Geoffrey CHAUCER, Canterburyjske priče, Zagreb, Znanje, 1986.

${ }^{35}$ Alexandre DUMAS, Tri mušketira, Opatija, Otokar Keršovani, 1994.

${ }^{36}$ Henryk SIENKIEWICZ, Križari, Zagreb, Zora, 1960

${ }^{37}$ Marija JURIĆ-ZAGORKA, Kći Lotrščaka, Zagreb, Školska knjiga, 2006.

${ }^{38}$ Ivo ANDRIĆ, Travnička hronika, Zagreb, Konzor, 2001.

${ }^{39}$ Babić, Vekić, Od Lutvine kahve...
} 
Pri navođenju lokacija neinduciranog pripovijedanja, ne smije se izostaviti ni bućalište (teren za igranje balota/buća) koje je usko vezano za gostionicu ili kafić. Bućalište je u mediteranskom kontekstu važno mjesto okupljanja muškaraca koji u društvu zajednice nastoje provesti vrijeme u igri i zabavi, no često takva okupljanja znaju iznjedriti primjere usmenoknjiževnih sitnih ili retoričkih oblika. Te lokacije su mjesto svakodnevnog druženja muškaraca u Dalmaciji i na tim lokacijama, osim svakodnevnih, javljaju se ponekad i priče koje su stilizirane u šaljivom tonu te često imaju funkciju mikrostrukture vica. Šaljive priče koje se pričaju na tim lokacijama često obiluju vulgarizmima, grubim govorom i psovkama. Ponekad se na tim mjestima mogu čuti fragmenti raznih vjerovanja pa tako i vjerovanje da opeklinu, čir i bol u vratu može otkloniti izmet šarene svinje: »A ako ćeš da ti prođe vrat, metni na nj balege od šarovite gude! ${ }^{40}$ No, svi oni promatrači koji se nalaze na tim mjestima, a nisu uključeni u aktivnosti kojima se drugi bave, pripovijedaju svakojake priče, bilo da je riječ o onim iz svakodnevnog života, onim iz prošlosti ili pak šaljivim i vulgarnim pričama. Zbog dinamičnosti događanja i vedre atmosfere u kojoj se nalaze, priče oblikuju tako da su one koncizne, dinamične, s početkom bez okolišanja i često sa šaljivim preokretom ili poantom. Osim toga, pozornost slušatelja znaju probuditi početnim frazama i izjavama poput: »Slušaj vamo!«, »A pazi sad ovo!«, »E, a da ti kažen ovo!«, »Nije to ništa, slušaj ovo!« itd.

Prostor gostionice ima drugačiju doživljajnu kategoriju od ognjišta u kućanstvu. Gostionice i »kafići« predstavljaju kulisu intimnog prostora na lokaciji koja je javnog karaktera. Specifičnost takvog odnosa vidljiva je u informacijama koje se mogu dobiti u tim prostorima. U razgovornim i pripovjednim situacijama u gostionicama često se prelazi granica između privatnog i javnog. Tijek razgovorne situacije često započinje izmjenom trivijalnih informacija i općih opažanja u zajednici. No, ovisno o situaciji i potrebi sudionika, ubrzo se iznose informacije iz privatnih života i iskustava, a nerijetko i privatne spoznaje o nekim članovima zajednice. Ovisno o koherentnosti društva koje se okupi $\mathrm{u}$ gostionici, razmjene informacija mogu biti privatnog i intimnog karaktera. Različito od pripovijedanja uz ognjište i uz vatru na otvorenom, u gostionici se predaje $s$ fantastičnim elementima se ne pripovijedaju. Pripovijedanja su sažetija i često obiluju vulgarizmima kojima se pojedinac pokušava afirmirati u društvu. Vicevi, anegdote, šale, »šifrirani razgovori« i pričanja iz života najčešći su oblici pripovijedanja na ovim lokacijama. Javna narav gostionice onemogućuje sugovornike da koriste pripovijesti i predaje da bi izrazili svoje stavove i mišljenja te se oni okreću sažetijim formama pripovijedanja da ne bi pali u nemilost sugovornika koji su nemilosrdni u kritici načina izvođenja nekog kazivanja. U gostionicu najčešće dolaze muškarci, gotovo isključivo. Ono što je specifično, a i univerzalno za ove objekte jest to da, prema mišljenju sudionika, kvalitetna gostionica mora imati ženu koja će usluživati mušterije. U

\footnotetext{
${ }^{40}$ Kazivao Klemo Bebić, a zapisao Denis Vekić, 17. lipnja 2009. u Metkoviću.
} 
razgovoru s radnicama u ovakvom objektu često se može čuti prijezir prema gostima koje nazivaju »muškim babama« jer se, prema njihovu mišljenju, odaju traču i trivijalnim pričama. Ponekad se može čuti i autoironija sudionika koji svoje razgovore komentiraju rečenicom: »Evo sidimo i gledamo 'ko će koga više slagat'.«

Iz navedenog proizlazi da bi bilo zanimljivo više proučiti usmenoknjiževne oblike koji se prenose na ovom mjestu koje može biti plodno tlo za daljnja istraživanja, posebno zbog toga što nije valjano istraženo, a aktivno je mjesto spontanih kazivačkih situacija.

\section{Na bdjenju uz pokojnika}

Posebno je zanimljiv usmenoknjiževni kontekstualni specifikum koji se manifestira u praksi pričanja priča dok se bdije uz pokojnika u kući. Ta praksa održala se u dolini Neretve sve do otprilike 2000. godine. ${ }^{41}$ Važno je istaknuti da se ovaj oblik pričanja odvija u noćnoj atmosferi uz prisustvo pokojnika u lijesu i upaljene svijeće, no nije svaka takva situacija rezultirala vrijednim narativima. To je situacija izuzetne sociološke i obiteljske kompleksnosti i osjetljivosti te se ne može očekivati jednaka neinducirana kazivačka situacija i korpus usmenoknjiževnih narativa kao u slučajevima spontanih okupljanja u noći oko vatre na ognjištu. O praksi bdjenja nad pokojnikom u Sinjskoj krajini pisao je Ivan Lovrić:

»Mrtvac redovno prenoćuje u kući, a rođaci, susjedi i prijatelji dolaze da mu budu društvo, da se ne bi uzelo za zlo, kad bi bio ostavljen sam. U takvim se slučajevima mora uvijek naći čovjek koji umije čitati kakvu knjigu, a ta je obično dosta slična knjizi Prato Fiorito (Cvjetna livada), prikladnoj da još ojača sujevjerje, mjesto da ga ukloni. Ali da društvo može što pažljivije slušati čitaoca i da ga ne svlada san, pije se rakija i tako se uz čitanje i nazdravice dočeka novi dan. $\ll^{42}$

Pripovijedanja uz pokojnika slične opisuje i Luka Ilić Oriovčanin:

»U večer obično dojdu ljudi - osobito u zimno vrěme pohajdat mèrtvaca. Tud se divani o pokojnika životu, o duhovih, kako mèrtvi hodaju i lupaju noćom it. d. dok se svi najposlě u onoj starorimskoj poslovici neslože: 'de morluis nil nisi bene'.. ${ }^{43}$

Frano Ivanišević općenito opisuje bdjenja uz pokojnika koja su zanimljiva zbog navođenja kazivačke prakse, ali i boravka oko vatre te se time spomenuta

\footnotetext{
${ }^{41}$ Događaj se zbio krajem 1990-ih u Metkoviću u dolini Neretve kojem je svjedočio Denis Vekić, a zapisao 2007. godine u Metkoviću.

${ }^{42}$ Lovrić, Bilješke o putu po Dalmaciji..., 177.

${ }^{43}$ Ilić Oriovčanin, Narodni slavonski običaji..., 308.
} 
mjesta i situacije koje se obrađuju u ovom radu spajaju u kompleksniju sliku međuprožimanja:

»Pozatin otpočinu u kući ili ako je zima, iđu uz oganj pa se razgovaraju, a domaćin iznese vina i nudi svakoga pit. Okolo velikog mrca plače i navije rodbina, koga srce boli. (...) Obnoć se svit razgovara, ali sve potijano, ne viče se, ne smije se niko, a prid zoru nosi se rakija i daje pit. (44 $^{44}$

Stjepan Hranjec, opisujući običaj bdjenja uz mrtvaca, navodi:

»Navečer bi se odvijalo varestovanje/verestovanje, bdjenje uz mrtvaca. (...) Muškarci bi u susjednoj prostoriji kartali, pili, rihtali se, ali su te duge noći bile istodobno i prigoda za razne pripovijesti koje bi u osobitom okruženju (pokojnik, noć) bile naglašeno dojmljive. « ${ }^{45}$

Bez obzira na geografske udaljenosti prostora o kojima su navedeni istraživači pisali, uočava se vrlo slična kazivačka situacija u kojoj se noću bdije uz pokojnika te se može reći da je taj rijetko opisani događaj iz prošlosti bio zaista kazivačka posebnost u kojoj su se odvijale neinducirane kazivačke situacije.

Izgradnjom mrtvačnica, mijenjaju se i prilagođavaju obredi koji se odvijaju u domaćinstvu nakon što im član obitelji umre. Nakon devedesetih godina 20. stoljeća obitelji surađuju s pogrebnim poduzećima te se mrtvac još istog dana prenese u mrtvačnicu tako da se bdjenje ne odvija cijelu noć već nekoliko sati dok je pokojnik još u kućanstvu. Prije suradnje s pogrebnim poduzećima obitelji bi u kućanstvu čuvali umrlog sve do trenutka dok ga se ne iznese iz kuće u pogrebnoj povorci. Na taj način, mrtvac je obavezno trebao biti čuvan u kući barem jednu noć. Za to vrijeme domaćinstvo je posjećivalo mnoštvo ljudi sve do u kasnu noć. Osim specifičnih oblika pogrebnih obreda koji su u pojedinim mjestima i selima uključivali gozbe u domaćinstvu umrlog, uobičajena praksa je bila da se te dane, kada u kući leži mrtvac, ne poslužuje hrana posjetiteljima. Kada bi pala noć i kada bi bilo vrijeme za počinak, uz odar s mrtvacem bi dobrovoljno ostajali oni pojedinci koji su na taj način odavali počast pokojniku. No, osim odavanja počasti i svojevrsnog procesa opraštanja od umrlog, bdjenje nad mrtvacem se odvijalo i iz praktičnih razloga jer se na taj način htjelo biti na oprezu u slučaju da se mrtvac probudi. Ako bi se takvo što i dogodilo, bdioci bi alarmirali kućanstvo i pomogli "probuđenom « mrtvacu. U takvim prilikama bi se bdjelo samo uz svjetlost lumina i dodatne svijeće. Bdjenje bi počinjalo onda kada bi u kući ostali samo oni koji su najbliži pokojniku. Kako bi se skratilo vrijeme bdjenja, pričale su se pokojnikove dogodovštine i opisivala dobra djela koja je ovaj počinio. Kada bi se pričanje proširilo i sudionici opustili često bi se pripovijedale predaje koje su u sebi nosile elemente stravičnog i mračnog. Nerijetko su se pripovijedale predaje o vukodlacima, morama i fantastičnim iskustvima i događajima na grobljima. Kroz ta pripovijedanja se mogu prepo-

\footnotetext{
${ }^{44}$ Ivanišević, Poljica..., 408-409.

${ }^{45}$ Stjepan HRANJEC, Međimurski narodni običaji, Čakovec, Zrinski, 2011, 269.
} 
znati i neka vjerovanja koja se odnose upravo na bdjenje i pokapanje mrtvaca. Tako se može čuti da nije dobro da mačka preskoči mrtvaca, ni da prođe ispod odra, te da nije dobro da životinja uđe u prostoriju s odrom, a posebno se zazire od muha u prostoriji. Bdioci, a i ukućani za vrijeme dana. tjeraju sve muhe koje vide i objašnjavaju da je to zbog toga što ne žele da se na leš skuplja »gamad«.

Tematski i motivski korpus pripovijedanih predaja je jasno definiran i određen karakterom pripovjedača. No, nerijetko se događa da prisni razgovori između bdioca, kroz razgovore o pokojniku, prerastu u večer ispunjenu šaljivim pričama i zabavnim dogodovštinama iz pokojnikovog života. Iako na prvi pogled takav pristup izaziva zgražanje ukućana, naposljetku se takav pristup prihvati kroz uvjerenje da je to lijep i prijateljski način oproštaja od pokojnika. Slično je opisao i Lovrić u navedenom tekstu, da se uz čitanje i nazdravice dočeka novi dan.

Prostorija u kojoj je mrtvac izložen je najčešće spavaća soba iz koje je iznesena postelja i svi predmeti koji bi mogli odvlačiti pozornost. Uz zidove se postave klupe i sjedalice za sve one koji će doći da mogu sjediti. Na taj način spavaća soba, koja je bila najintimniji dio kućanstva za pokojnika, postaje sada prostorija javnog karaktera dobivajući funkciju mjesta susreta gostiju i domaćina kuće. Na jedan dan u domaćinstvu ta soba je javno mjesto okupljanja uže i šire rodbine, prijatelja, poznanika pa i stranaca koji su poznavali pokojnika. No, kada je riječ o transformaciji prostorije iz privatne u javnu, važno je istaknuti da dolaskom noći ta ista prostorija postupno postaje ponovno intiman prostor, ali u funkciji povezivanja obitelji s onim gostima koji su bili blisko vezani s pokojnikom. Time se nanovno ostvaruje funkcija privatnog prostora koji na jednu noć poprima specifičnu ulogu. Tom prilikom članovi šire obitelji i rodbine ponekad traže način da se povežu s mlađim generacijama da bi im ispripovjedili pojedinosti iz života pokojnika.

Čest retorički postupak u pripovijedanju je obraćanje pokojniku, a onda sugovornicima. Na taj način se ostvaruje kompenzacijski aspekt te ostaje dojam da je i pokojnik živi sugovornik i sudionik. Kazivač Nikola Nikolić iz Matijevića je napomenuo da zna nekoliko slučajeva bdjenja gdje su se pokojnikovi prijatelji uz priču gostili vinom ne bi li lakše podnijeli prijateljevu smrt, da bi se u kasnim noćnim satima opili te čak i zapjevali pjesme iz njihove mladosti i zaspali na klupama oko odra. ${ }^{46} \mathrm{Da}$ su se pričale i šaljive priče svjedočio je i Josip Milićević koji je opisivao narodne običaje i vjerovanja u Sinjskoj krajini. ${ }^{47}$ On također svjedoči da se u vrijeme noćnog bdjenja uz mrtvaca pripovijeda o životu i doživljajima pokojnika, te da se pričaju i druge priče, čak i šaljive. Također, u kućanstvu gdje leži mrtvac izvode se naricanja i tiho pričanje. ${ }^{48} \mathrm{Na}$ taj način

\footnotetext{
${ }^{46}$ Kazivao Nikola Nikolić, a zapisao Denis Vekić 15. lipnja 2007. u Metkoviću.

${ }^{47}$ Usp. Josip MILIĆEVIĆ, Narodni običaji i vjerovanja u Sinjskoj krajini, Narodna umjetnost hrvatski časopis za etnologiju i folkloristiku, 5-6 (1967) 1, 433-511, 468.

${ }^{48}$ Usp. Ivanišević, Poljica..., 408-409.
} 
prostor u kojem je pokojnik izložen postaje vrlo intiman, da se čak i ukućani ponekad ne usuđuju stupiti u nj dok se pojedinci opraštaju s pokojnikom. Znak je to dubokog poštovanja privatnog diskursa i intime koja proizlazi iz situacije. Prisjećajući se dogodovština iz djetinjstva pred pokojnikom sami kazivači prostoru daju novu dimenziju privatnog gdje se posljednji intimni rastanak odvija na mjestu gdje je pokojnik za života spavao te se prijelaz u smrt promatra i kao utonuće u san. Prostorija u kojoj je izložen pokojnik više nikada neće imati istu funkciju u sjećanju pojedinaca jer su svjedočili njenoj transformaciji u duhovno intiman prostor.

O sličnim tradicijskim tekovinama na Hvaru svjedočio je Dragutin Jeličić koji je opisao običaj molitve i pripovijedanja o mrtvacu osam dana od dana pokopa. ${ }^{49}$ Običaj koji imaju Hercegovci uz samu geografsku granicu s Hrvatskom u dolini Neretve, a time se misli na područje današnje općine Ljubuški, tiče se pripremanja gozbe na sam dan pokopa pokojnika. Nakon pogreba i pokopa, u pokojnikovoj kući obitelj pokojnika priprema gozbu, ili kako je u dolini Neretve nazivaju daća, za sve koji su došli na sprovod. Na toj gozbi se također pripovijedaju događaji iz pokojnikova života, no zbog atmosfere koja se odvija danju i zbog prisutnosti većeg broja gostiju, ne može se ostvariti intima pripovijedanja kao za vrijeme bdjenja, prevladavaju memoari, pričanja iz života te pričanje iznimnih događaja iz pokojnikova života. Korpus predaja koje se pričaju na bdjenju i naknadnom okupljanju kod pokojnikove obitelji raznolik je i uključuje pričanja iz života, demonološke predaje i šaljive priče.

\section{Zaključak}

Istraživanje je usmjereno na proučavanje potencijalnih umjetničkih usmenoknjiževnih tekstova koji su nastali kao rezultat terenskog zapisivanja tvorevina nastalih u induciranoj kazivačkoj situaciji. Najviše zabilježenih usmenoknjiževnih vrsta nastao je induciranom kazivačkom situacijom gdje istraživač sjedi zajedno s kazivačem i snima/bilježi usmenoknjiževne vrste koje mu kazivač iznosi. U takvoj situaciji odnos kazivača i prikupljača jest recepcijskog karaktera, ali treba obratiti pozornost na to da se u takvom kontekstu prijenos usmenoknjiževnog sadržaja odvija u gotovo umjetnim i nimalo spontanim uvjetima. Tek kada se razvije povoljna situacija i opuštenost kazivača može se približiti neinduciranom obliku kazivačke situacije, obliku koji je sveprisutan u svakodnevnoj komunikaciji prošlih vremena u kojoj kazivači nisu promatrani kao kazivači niti su u toj zajednici bili prikupljači usmene književnosti koji bi mogli napraviti takvu podjelu.

\footnotetext{
${ }^{49}$ Usp. Bošković-Stulli, Žito posred mora..., 30.
} 
Prilikom terenskih prikupljanja građe koristi se najčešće metoda polustrukturiranog intervjua te se tako stvara inducirana kazivačka situacija, no za vrijeme kazivačkih situacija spontano bi se priključivali i drugi kazivači koji su usputno prolazili kroz domaćinstva u kojima su se prikupljana kazivanja održavala. Pridruživanje drugih kazivača i njihovo ubacivanje u pripovijedanje kazivača stvaralo bi novu atmosferu koja je na trenutke izgledala poput neinducirane kazivačke situacije.

U ovom radu predmet istraživanja bio je upravo kontekst neinduciranih situacija koje su se u raznim istraživanjima pokazala kao najčešća (pričanje oko vatre), društveno uvjetovana (pričanja u gostionici/krčmi/kafiću) te kontekstualno specifična (pričanje na bdjenju uz pokojnika). Proučavanjem značenja vatre, kao mediološkog posrednika u komunikaciji ljudskog društva od prapovijesnih vremena sve do suvremenosti, uočava se da dominira u učestalosti induciranja kazivačkih situacija. O tome svjedoče sami prikupljači na terenu, kazivači i zajednica u kojoj se takav oblik pripovijedanja odvijao. Značenje vatre imalo je funkcionalnu, sociološku i intimnu funkciju u zajednici postavivši se, putem ognjišta i otvorenih ložišta, u specifičnu ulogu povezivanja članova zajednice. Osim toga, svojom funkcijom, emisijom topline i svjetla postala je i poticatelj mašte i svih onih iracionalnijih aspekata čovjekove misli te je svojim izgaranjem postala pogodan poticatelj za izražavanje usmenoknjiževnog umjetničkog izričaja koji se proteže kroz većinu usmenoknjiževnih vrsta.

Sličnu mediološku funkciju imaju gostionica/krčma/kafić koji samom svojom svrhom i funkcijom postaju društvena kulturološka i komunikacijska sjecišta u kojima pripovijedanje zauzima važnu poziciju u komunikaciji članova zajednice. Navedeni objekti imaju funkciju javnih prostora u kojima članovi zajednice prikupljaju i šire informacije vitalne za pojedini društveni krug. Prikupljanje usmenoknjiževne građe na ovim mjestima je vrlo zahtjevan posao i često narušava hermetičnost atmosfere i funkcije koju gostionice/krčme/kafići imaju. Zanimljivo, gostionica je zauzela arhetipsku funkciju u književnosti te autorima poslužila kao pokretač radnje ili opće mjesto zajednice koja izmjenom informacija nudi početnu točku naracije. Uz navedene lokacije pripovijedanja još su značajni i tereni za igranje balota koji u igračima imaju potencijal za daljnja istraživanja usmenoknjiževnih mikrostruktura.

Treći dio rada promotrio je onu kazivačku situaciju koja je ovisna o specifičnoj društvenoj situaciji. Riječ je o kazivanjima na bdjenju uz pokojnika koje se odvija u domaćinstvima u kojima pokojnik umre. Ta kazivačka situacija je bila jako specifična i sada je već dio prošlosti te više ne postoji u suvremenim domaćinstvima što zbog državnih zakona, što zbog novih običajnih praksi suvremenog društva. Kazivačka situacija koja nastaje na bdjenju uz pokojnika vrlo je teška za istraživanje. Osim što je sada već gotovo nemoguće podrobnije proučiti kazivačku vrijednost ove situacije, postoji niz zapreka društvene i intimne prirode. Ivan Lovrić, Luka Ilić Oriovčanin i Frano Ivanišević su u svojim priku- 
pljačkim aktivnostima i iskustvom življenja posvjedočili o usmenoknjiževnom izražavanju na bdjenjima uz pokojnika i ti zapisi čine vrijednu etnografsku zanimljivost. No, istraživač jednostavno ne može prisustvovati ovoj specifičnoj kazivačkoj situaciji i bilježiti sve kazivano stoga što bi poremetio iznimno delikatnu i intimnu atmosferu koja obilježava bdjenje. Njegova prisutnost, pa čak i kada bi to radio potajno, suprotno svim moralnim i društvenim civilizacijskim vrijednostima, narušila bi visoku duhovnu razinu događaja i prilikom iznošenja sadržaja prikupljene građe ogriješio bi se o osobnu intimu zajednice i pojedinca. Stoga je ova kazivačka situacija svojevrstan kulturološki specifikum, ali i velik društveni i obiteljski tabu za sve vanjske članove zajednice. Atmosfera koju gradi ova kazivačka situacija je superiorna drugim kazivačkim situacijama, posebno kada se pripovijedaju priče čija je funkcija strašenje ili usađivanje mitskih i demonoloških obrazaca vjerovanja koji se najbolje pamte uz prisutnost pokojnika koji kao da svojim postojanjem jamči istinitost tih priča čija je tema smrt i zagrobni život.

\section{Denis Vekić* \\ Locations of oral storytelling - storytelling around the fire, in the inn and on the deceased watch \\ Summary}

The paper deals with the locations on which oral literature is created and told focusing on a communication aspect which those locations, suitable for oral literacy, encourage. Attention is devoted to the context of oral literature which is transmitted by members of society gathered around the fire. Some recent experts consider fire to be one of the basic factors of information development of ancient societies. This paper observes the inn/bar/cafe as a place suitable for a fertile oral literature display mostly because of the sociological and anthropological value of these locations in the exchange of information of one society. Finally, the paper deals with a specificity in the oral literature transmission function - appearance of storytelling and other oral narratives while the household and the family are on deceased watch. Contrary to storytelling around fire and in the inns, this narrative specific is manifested despite the delicacy of the situation and atmosphere which is believed unsuitable for storytelling.

Key words: fire, inn, oral literature, storytelling.

(na engl. prev. Denis Vekić)

\footnotetext{
* Denis Vekić, PhD, Department of Croatian and Slavic Studies, University of Zadar; Address: Obala kralja Petra Krešimira IV., br. 2, HR-23000 Zadar, Croatia; E-mail: dvekic@unizd.hr.
} 